\title{
E-Commerce Product Description Model for Start Up
}

\author{
Mochamad Malik Akbar Rohandi, Dheka Dwi Agustiningsih, Firly Firmansyah Sumpena, and Eka Tresna Gumelar \\ Department of Management \\ Bandung Islamic University \\ Bandung, Indonesia \\ moch.malik@unisba.ac.id
}

\begin{abstract}
This paper discuss the product description of halal make up specifically for lipstick in e-commerce. According to Global Islamic Economy Report 2016/2017 halal pharmaceutical and cosmetics is becoming a growing sector and expected to reach $\$ 213$ billion by 2021 in aggregate. E-commerce gives everyone the opportunity to become a seller or intermediary by utilizing existing market space. Therefore, it is necessary research to know the material description of halal cosmetics products are sold. The aims of this study to build a description model of halal lipsticks as a cosmetics products can attract buyers until the purchase decision. The method used in this research is qualitative method with exploratory research approach. Observation was conducted on Tokopedia.com, sampling using Bernoulli method (2010). McGuire's Psychological Motives used to determine the consumers basic needs of a product (2010). To analyze product description use the theory of persuasion in the advertising by $\mathbf{J}$. O'Shaughnessy and N. J. O'Shaughnessy (2004) and Toulmin's theory of argument (1958). The result shows that the products of halal cosmetics has used the type of persuasive description which contains the elements of argument. Those elements include claim, data, and warrants. According to Toulmin, to build a product description model requires at least three elements of argument mentioned above. The claim can actually be in the forms of halal, originality, security, and other basic needs. In short, the research result implies the efficacy for entrepreneur of halal cosmetic to make the description of appropriate products.
\end{abstract}

Keywords—halal; cosmetics; ecommerce; product description; persuasion; argument

\section{INTRODUCTION}

Internet users around the world today have reach 3.8 billion, equivalent to $51.7 \%$ of the world's population (www.internetworldstats.com)[1]. This triggers a change in purchasing behavior, many conveniences offered by seller. Technological developments change the way a person in buying and selling a product, sellers do not have to have physical place, they can take advantage of e commerce media.

E-commerce media that have ubiquity, make everyone have the opportunity to become a seller even though they do not have the product that is with an affiliator. Digital marketing takes advantage of existing marketplace media, its one of the main concerns in recent years and needs a persuasive approach.

The development of marketplace media in Indonesia is very promising when looking at the data from The Central Bureau of Statistics (BPS) in 2016 which states that this industry grew $17 \%$ or with a total number 26.2 million business units [2]. Bloomberg itself issued an analysis that in the year 2020 almost half the population of Indonesia will be involved in e-commerce activities [3], while in the Mckinsey report "Unlocking Indonesia Digital Opportunity" said the switch to the online store will increase Indonesia's economic growth to $\$ 150$ billion in 2025, in the report also disclosed that the use of the Internet through mobile media, especially smartphones will increase by $73 \%$ and will continue to grow in line with the increasingly widespread infrastructure in Indonesia [4].

In the pharmaceutical and cosmetic statista.com showed a change in world consumer behavior in buying cosmetic products by $37 \%$ online [5], while in Indonesia sales reached $\$ 139$ million or up $35.7 \%$ from 2015 (ecommercefoundation.org) The purchase of cosmetics halal Muslim world in 2015 reached $\$ 56$ billion, Indonesia spent up to $\$ 3.3$ billion from total world cosmetic expenditure reaching $\$ 750$ billion, it is becoming a growing sector and expected to reach $\$ 213$ billion by 2021 in aggregate [6]. This the opportunities for Muslims in Indonesia to take this advantage by utilizing e-commerce in marketing can be reached by consumers around the world is not limited to Muslims it self. The overall make up on cosmetics category reached $20 \%$, with the biggest expenditure on lipstick products than other products.

Halal products are created from the processes in accordance with Islamic Shari'a [7]. The product must use materials, names and characteristics [8] that are in accordance with Majelis Ulama Indonesia (MUI) fatwa related to Halal products (SK 13 / Dir / LPPOM MUI / III / 13). The word halal itself in the Indonesian Dictionary means "permitted" or obtained in a manner consistent with the Islamic Shari'a.

One disruptive marketing in the world is the development of online marketing that changes the competition map, the consumer as the main subject becomes a driver for other consumers to benefit from the products used [9]. There are four things that distinguish the traditional marketing that is, more personal, participatory, peer to peer and communal [10].

There are five stages in making the purchase decision process is problem recognition, information search, evaluation of alternative, purchase decision and post purchase behavior [11][12]. Information search is closely related to the need where information can be obtained through several sources such as personal sources, commercial sources, public sources and experiential sources [13].

The habits of consumers to conduct advance information search, need a content that can attract potential customers before they make a purchase decision, so that need a content can attracting the memory even though it is online [14]. 
There are no hard and fast rules as to what types of content you should use in digital marketing, it depends on target audience, buying cycle, think plural and do not just take the easy street [14]. One of the reasons for using content marketing is that it can change consumer behavior. The research showed $61 \%$ of consumers currently search for information online and $44 \%$ make purchases online [14].

To make the product description content, it is necessary to convey persuasive messages, the conscious intention of one party to influence or motivate the other to believe or willing to do something that can make or change attitudes and create confidence. The Description argument type, has potential to evoke emotions by connecting feelings focusing to produce perspective changes, when the words used represent a very important thing [15]. Trust of a product is the most important thing in the online shopping, because in the online store can only display images with product description text [16]. It takes a product description that can convince the customer especially for products that have an expiration date [17].

Agustiningsih mentions that the argument is formed from the major, minor premises and a conclusion based on mathematical logic that serves as a supporting word or phrase or criticizing statement. Toulmin says that every expression always has the actual recognition, it can be a supporting sentence or even a rejection. An argument will be stronger if accompanied by supporting data accompanied by a guarantee [18].

Content text serves to keep the reader's attention. Contains messages can be sales, raises arguments, summarizes the evidence and gives an explanation [19].

In the e-commerce industry with the largest business model Consumer to Customer (C2C) in Indonesia tokopedia.com, almost all product descriptions of halal cosmetics products, especially lipsticks, are duplicated from existing competitor accounts.

In this research will be discussed about the description model of cosmetic products especially halal lipstick which is sold in e commerce tokopedia.com, to be used as a reference material and facilitate the beginner in making effective product descriptions in the world of e commerce.

\section{RESEARCH METHOD}

This study uses qualitative methods to provide information about the reasons behind consumer behavior. Common research methods are observation and case studies. Researchers used qualitative data analysis techniques related to product descriptions of every halal lipstick product that became the research sample so this research was also an experimental research used to test marketing factors and the attractiveness of the implementation of advertising in terms of product features, price, availability and creative advertising ideas [15]. Powered by Content analysis in advertising that can provide guidance on how to think competitively and provide the basis for developing new, more effective campaigns [15]. Based on the findings in the study. The case study approach will increase more than one way to obtain data about the case or object from the research [20].
The object of this research is tokopedia.com is the best e commerce in Bandung in terms of the use of language that is easy to understand [21]. The population in this study were all seller accounts that used the keyword "Halal Lipstick" in a total of 506 accounts as of October 17, 2017. All data collection was obtained using secondary data [22].

Determination of the number of samples is done by using probability sampling, the best data collection for visitor of web site use random sampling [23], the number of samples of halal makeup (lipstick) product using bernoulli method [23], with a $10 \%$ error rate to obtain a total sample of 96.06 that is computed to 100 .

\section{RESULT AND DISCUSSION}

This research was conducted two stages of analysis. First, the analysis of propositions. Second, argument element analysis. Review one by one against the proposition in the product description. Then, analysis of argument elements in the form of claim, data and warrant. The number of claims, data, and warrant in the product description of the author thoroughly amounted to $59.77 \%, 33.34 \%$, and $4.88 \%$, respectively. This shows that the largest portion contained in the description is claim, then data, and at least is warrant.

Claim is a statement believed to be true by the author of the product description. Claims can be opinions, attitudes, or conclusions. From the product description samples analyzed there are claims regarding product originality assurance, halal, differentiation from other products, product prices, product superiority, product popularity, effects of product use, product usage time, solicitation or impetus for product use, and product availability.

Data is the reason that serves as a support for the claim can be accepted and believed. The data is a reason, the evidence used to support the statement presented as the basis of a claim. One form of relationship that occurs between claim and data is a causal relationship marked by a conjunction / because /. The data found in this analysis are the support of product originality, facts about product differences, product price differences, data on product superiority such as product safety, color, and product usage; data about the popularity of products in Muslim / Muslim environments that worship Hajj / Umrah; the facts of the use of the product, the mention of data on the time limit of the use of the product, the reasons that invite people to use the product one of which is to please the couple, as well as the type of color available from the product.

Warrant is a statement that shows the principle, law or general rule to defend claim. Warrant is a link between data and claims that show the suitability of both. To find warrant researcher see the relationship between data and claim and seek explanation for claim can be accepted rationally. In this analysis warrant can be accepted as a guarantor claim or persuasion submitted by the seller regarding the originality of the product that is the serial number NA BPOM 47161301704 and/or the presence of gold sticker serial number 33 .

The claims submitting technique in this product description is a statement that the seller believes to be true in the form of a sentence such as /Lipstik hare arab versi Taiwan/ This sentence is a seller's statement about the product. Sentence /Dioles 
langsung pink ya/ is a claim because it is a seller's statement that shows the seller's opinion about the product which if used or applied on the lips will directly produce a pink color. Researcher statement about the time limit for use of the product is also a claim. This is as shown in claim number 12 that is / Date exp: November 2019 /. The other is a magical / Lipstick hare ajaib / as it is different from any other lipstick. The statement that Hare is different from ordinary lipstick is the opinion of the sellers about the product. The sellers tries to distinguish the product he sells with other similar products. In addition, the claim is also represented in a sentence such as / Buat apa beli murah beberapa ratus perak tetapi $\mathrm{kw}$ ?/.

In addition to the form of a sentence, the claim is also represented in the form of words, affixes, and conjunctions. Use of word / sudah tidak asing lagi /. This phrase gives an explanation of the adjective in the proposition which means it is (the case, the circumstances, etc.) or so. Word / jamin / means "responsibility". The word / Ayo / the proposition / Ayo senangkan pasangan anda / is an exclamation point to declare a solicitation or give encouragement. Propositions with the use of the word / ayo / above can also be categorized in imperative sentences of solicitation or hope. Then, the formation of word / senangkan / derived from word / senang / with the suffix / -kan / can give meaning "do ...". This suffix is applied to a senang word that states the action so that when added with the suffix, it has the function as a command line. Thus the proposition also states an opinion.

The affixed / di / in / dijamin / is a verb-forming prefix of a person subject to an action, which is guaranteed or borne. This kind of affirmation is also present in other propositions that function to verbs form. Verb formed this is a claim that states an opinion and attitude of the sellers. Conjunction / jadi / which is the range of conversations of the conjunction / maka / which has the function of conjunction inference.

To make a claim accepted or approved, the claim needs to state the reason or data. The data used in the product description is the reason or support for the receipt of a claim. The marker for data, is the conjunction / karena / which states the causal relationship, the conjunction that states the relationship of the result (for, in order, if, so), the conjunction that states the relation (jika, in case). The existence of data that always exist for a claim shows that claims and data are interrelated.

Another analysis is an analysis of the argument elements contained in the product description that form the description model. This is done to find out the best model. The best description model that can be formed to produce the best product description is by arrangement of argument elements as follows:

Composition 1 Data-Warrant-Data-Claim rate of use of $46.15 \%$, highest sales rate of $441.67 \%$. Composition 2 DataData-Data-Claim rate of use $15.38 \%$, highest sales rate of $246.676 \%$. Composition 3 Data-Data-Claim-Claim rate usage $15.38 \%$, highest selling rate $92.31 \%$. Composition 4 Data-DataWarrant-Data usage rate of $7.69 \%$, highest sales rate of $166.67 \%$. Composition 5 Warrant-Data-Claim-Warrant usage rate of $7.69 \%$, highest sales rate of $71.79 \%$. Composition 6 DataClaim-Claim-Claim rate usage $7.69 \%$, highest selling rate $34.29 \%$.
Composition argument element No. 1 is used by $46.15 \%$ from the total research sample with the highest sales rate of $441.67 \%$ so it can be said that this composition is the best composition among others, where consumers can feel reassured by the composition of data, claim and warrant contained in the description of the product.

\section{CONCLUSION}

Based on the analysis and discussion that has been done there are several findings, namely:

First, findings about the element of argument in the product description. Claim is the highest in the description of the product that is equal to $59.77 \%$, and Warrant is the least used argument element that is equal to $4.88 \%$.

Second, the argument elements found in the product description are claim, data, and warrant. Other elements in the form of backing, qualifier, and rebuttal are not found. This means that the argument used in this product description meets the core elements of the argument because the three elements that are not found are only additional. Referring to Toulmin's view, the core of the argument is in three elements, claim, data, and warrant. Three other elements in the form of backing, qualifier, and rebuttal, can be used as needed or just as supporting words.

Third, the best compositions in composing argument elements are Data-Warrant-Data-Claim with usage rate of $46.15 \%$ and get the highest sales rate of $441.67 \%$. Compositions containing three elements of argument is the best model in creating a product description for start-up entrepreneur who sell halal cosmetics especially lipstick.

\section{REFERENCES}

[1] http://www.internetworldstats.com/stats.htm at accessed in 26 Agustus 2017

[2] Badan Pusat Statistik 2016

[3] https://www.bloomberg.com/news/articles/2017-10-17/big-data-is-newpush-for-bank-indonesia-as-it-reviews-rate-cuts accessed in 17 oktober 2017

[4] Kaushik. Das, Gryseels. Michael, Sudhir. Priyanka, and Tan. Khoo Tee, "Unlocking Indonesia's Digital Opportunity," McKinsey and Company, 2016.

[5] http://www.statista.com/statistics/692871/global-online-shoppingpreference-by-category accessed in 3 Oktober 2017

[6] State of the Global Islamic Economy Report 2016/ 2017, Thomson Reuters dan Dinar Standard, 2017.

[7] Wicaksono. Reki, "Halal Science," Journal of Halal Research Vol. 1 No. 1, 2015.

[8] Tieman. Marco dan Darun. Mohd Ridzuan, “A Supply Chain Approach Towards Halal," Journal of Halal Research Vol. 1 No. 1, 2015.

[9] Chaffey. Dave, "Digital Business and E Commerce Management 6th edition," Pearson Education Inc, 2015.

[10] Laudon, Kenneth C. and Traver, Carol Guercio. "E Commerce 2016", Pearson Education, 2017.

[11] Kotler. Philip and Keller. Kevin Lane, "Marketing Management 15th ed," Pearson Education Inc, 2016.

[12] Hawkins. Del 1 And Motherbaugh. David L, "Consumer Behavior: Building Marketing Strategy 11th Ed”, McGraw-Hill, 2010.

[13] Kotler. Philip and Armstrong. Garry, "Principles of Marketing 16th ed," Pearson Education Inc, 2016.

[14] Kingsnorth. Simon, "Digital Marketing Strategy,” Kogan Page Limited, 2016. 
[15] O'Shaughnessy. John and O'Shaughnessy. Nicholas Jackson, "Persuasion Advertising," Routledge, 2004.

[16] Lin. Fen-Hui, "The E Commerce Ideal Competition In Taiwan," International Journal Of Arts \& Science, ISSN: 1994-6934, 2011.

[17] Hanus, Gabriela, "Consumer Behaviour During Online Grocery Shopping," International Journal on Innovations in Science and Education, JEL 035, UDC 304, 2016.

[18] Agustiningsih, Dheka Dwi. Permatasari, Andalusia Neneng and Alhamuddin. 2017. The Argument on a student thesis of department of islamic education. International Journal of Education vol. 9 No. 2 Februari 2017
[19] O'Guinn. Thomas C, Allen. Chris T and Semenik. Richard J, "Advertising and Integrated Brand Promotion," South western, 2012.

[20] Greener, Sue. "Business Research Methods", Ventus Publishing, 2008.

[21] Rohandi. Mochamad Malik Akbar, "Effective Marketing Communication: Word of Mouth" Jurnal Manajemen dan Bisnis ISSN 1829-8680, 2016.

[22] http://www.tokopedia.com

[23] Zikmund. William G, Babin. Barry J, Carr. Jon C, and Griffin. Mitch, Business Research Methods, South Western, 2010 